\author{
MAREK MAGDZIAK \\ MARCIN STABROWSKI \\ Uniwersytet Wrocławski
}

\title{
Ontologiczne aspekty interpretacji dokumentów osobistych
}

DOI: 10.19195/2083-7763.7.11

W znanej pracy $O$ dziele literackim. Badania $z$ pogranicza ontologii, teorii jezyka i filozofi literatury Roman Ingarden ${ }^{1}$ zaproponował spojrzenie na dzieło literackie jako na twór o charakterze polifonicznym, będący organiczną całością złożoną z następujących po sobie kolejnych warstw. Zdaniem Ingardena te warstwy to: 1. warstwa brzmien słownych i budujących się nich językowych tworów brzmieniowych, 2. warstwa jednostek lub całości znaczeniowych różnego rzędu, 3. warstwa wyglądów i ich ciągów lub szeregów oraz 4. warstwa przedmiotów przedstawionych.

Oczywiście każde dzieło literackie może być potraktowane jako źródło pisane, lecz nie każde źródło pisane jest dziełem literackim. Dlatego można przyjąć, że podobnie jak dzieło literackie, źródło pisane jest organiczną całością mającą strukturę warstwową. Jednak warstwy, które w jego ramach należy wyróżnić, nie muszą dokładnie odpowiadać warstwom dzieła literackiego w ujęciu Ingardena. Co więcej, na źródło pisane patrzymy raczej z metodologicznego punktu widzenia, czyli inaczej niż Ingarden patrzył na dzieło literackie. Badania Ingardena miały charakter ontologiczny. Podstawowym pytaniem było to, jak istnieje dzieło literackie i czym ono jest. Rozważania dotyczące źródła pisanego mają zaś charakter metodologiczny. Podstawowym pytaniem jest zatem, czym może być i czym powinno być źródło pisane dla historyka i filozofa kultury.

Proponujemy zatem wyodrębnienie warstw źródła pisanego:

1. napisów i tworów graficznych,

2. językowych tworów brzmieniowych,

1 R. Ingarden, O dziele literackim, przeł. M. Turowicz, Warszawa 1960. 
3. jednostek lub całości znaczeniowych,

4. wyglądów,

5. wartości,

6. przedmiotów przedstawionych,

7. suponowanych sytuacji.

Spróbujemy uzasadnić ten dobór warstw, które proponujemy wyodrębnić w źródle pisanym.

1. Na początku jednak musimy odpowiedzieć na podstawowe pytanie, mianowicie, czym w ogóle jest źródło. Przede wszystkim jest ono zawsze źródłem czegoś. Dla badacza, w szczególności badacza kultury, jest ono źródłem wiedzy, a zatem czymś, co czyni możliwym poznanie, co je uzasadnia i uprawomocnia. Poznanie z kolei jest zawsze poznaniem czegoś, ma zawsze swój mniej lub bardziej określony przedmiot. Otóż dla badacza kultury przedmiotem takim jest świat przeżywany ${ }^{2}$. Czym zatem jest świat i czym jest świat przeżywany? Świata nie widzimy, tak jak widzimy drzewa, budynki, ludzi czy inne obiekty. Nie przypominamy ani nie wyobrażamy go sobie. Świat to nie tylko konglomerat czy nagromadzenie rzeczy, lecz przede wszystkim pewna organiczna całość, stanowiąca w stosunku do przynależnych do niego przedmiotów przedmiot wyższego rzędu. Widzimy, przypominamy sobie, wyobrażamy sobie, czy mówiąc ogólnie - bezpośrednio (lub naocznie) przedstawiamy sobie to, co przynależy do świata, a nie sam świat. Oczywiście takie bezpośrednie (naoczne) przedstawianie sobie tego, co przynależy do świata, jest niezbywalną składową obrazu świata jaki ujmujemy. Obraz taki jest jednak zawsze w sposób istotny dopełniony przez wiele innych składowych. Na przykład przez relacje zachodzące pomiędzy przynależącymi do świata, przedmiotami, wyglądy i wartości tych przedmiotów czy sytuacje, w które są one uwikłane. Wszystko to składa się na przeżywany przez podmiot obraz świata.

2. Jednak kiedy patrzymy na obraz świata, przeżywanego za pośrednictwem źródła pisanego, dochodzą do tego także inne składowe, charakterystyczne dla tego źródła i kształtujące postrzeganie tego obrazu. Są nimi po pierwsze twory graficzne, albowiem pismo to kształty. Kształty to także faktura papieru. Obok kształtów pojawia się też barwa, wraz z jej odcieniami. Powiemy za Ingardenem, że elementy te tworzą warstwę graficzną źródła pisanego. (Pomijamy tu zupełnie kwestię, czy w ramach tej warstwy mamy do czynienia z przedmiotami materialnymi i co to w ogóle znaczy, że przedmiot jest materialny, czy też z przedmiotami idealnymi, takimi jak kształty, typy czy barwy jako jakości idealne. Wszystko to,

2 Oczywiście takie ujęcie przedmiotu historii kultury nie jest jedynym ani nawet dominującym we współczesnych badaniach nad tą dziedziną. Jesteśmy jednak przekonani, że odświeżenie tej kategorii w badaniach społecznych, w szczególności w naukach o kulturze - a dokładniej ujmując zastosowanie metody fenomenologicznej - jest bardzo twórcze i wartościowe poznawczo. Należy także zauważyć, że u wielu fenomenologów (E. Husserl, M. Scheler, M. Merleau-Ponty) pojawiały się postulaty badań historycznych, dotychczas na gruncie nauk o przeszłości prawie niepodejmowanych, które wskazują na istnienie pomijanych dotąd aspektów źródeł. 
choć bardzo interesujące, wykracza znacznie poza obszar i objętość niniejszych rozważań). Należy tu zdecydowanie podkreślić, że warstwa ta jest istotna, gdyż stanowi składnik świata przedstawionego przez autora lub autorów rozważanego źródła. Dlatego w samym źródle pisanym mamy już coś, co jednocześnie przynależy do warstwy przedmiotów przedstawionych w obrębie świata przeżywanego przez autora lub autorów rozważanego źródła. Dla autora listu sprzed choćby dwustu lat istotnym składnikiem określającym jego obraz świata było także to, jaka będzie graficzna strona tekstu, który pisze. Jakiego użyje papieru, atramentu i pióra, i jakim charakterem pisma się posłuży. Wszystkie te przedmioty to $\mathrm{z}$ jednej strony narzędzia czy środki, a z drugiej - istotne elementy tej dziedziny przedmiotowej, której rzeczona komunikacja dotyczy.

Nie ulega wątpliwości, że dla historyka kultury jest to warstwa doniosła. Należy jednak dodać, że analiza warstwy graficznej źródła napotyka niekiedy trudności niepozwalające na uwzględnienie tej warstwy w rekonstruowaniu świata przeżywanego. Otóż historyk często nie ma po prostu dostępu do oryginalnego źródła. Po drugie, badania takie wymagają szczegółowego i analitycznego warsztatu oraz swoistej wrażliwości badawczej. Jednak specyfika warsztatu badawczego musi być dostosowana do przedmiotu, czyli w naszym przypadku świata przeżywanego, nie zaś świata naturalnego ${ }^{3}$. Tymczasem $\mathrm{w}$ dotychczasowych badaniach historia kultury materialnej koncentruje się na tym drugim ujęciu. Oczywiście osiąga przy tym niebłahe efekty i legitymuje się długą tradycją, dotyczącą jednak innego przedmiotu. Podobnie ma się rzecz z historią idei. W tej dziedzinie też zadaje się pytania o narzędzia pisarskie ${ }^{4}$ i ponownie podkreślić należy wagę takich badań oraz spostrzeżeń. Znowu jednak mamy do czynienia z odmiennym ujęciem przedmiotu badań. Nie ma wątpliwości, że zajmując się światem przeżywanym tekstów pisanych, powinniśmy uwzględnić tę warstwę graficzną, i że jest ona ważnym elementem świata przeżywanego. Na przykład czasochłonność wytworzenia danego źródła odsyła nas do problemu przeżywania czasu w badanej kulturze, z kolei faktura użytego materiału i sposób pisania pozwalają pytać o sensualność i zmysły w kulturze. Idzie więc o to, aby wypracować specyficzny dla badacza kultury zestaw narzędzi właściwych dla tej dziedziny przedmiotowej.

3. Warstwa tworów graficznych (wszystko jedno czy traktowana jako warstwa obiektów materialnych, czy idealnych) w przypadku źródła pisanego odsyła jednak zawsze do innej warstwy - pewnych czynności i rezultatów będących wytworami tych czynności. Zgodnie z Ingardenem obejmuje ona przede wszystkim językowe twory brzmieniowe. Każdy akt napisania jakiegoś słowa czy zdania jest bowiem nierozdzielnie związany z aktem wypowiedzenia go. Dlatego każdemu

3 Zob. E. Husserl, Kryzys europejskiego człowieczeństwa a filozofia, przeł. J. Sidorek, Warszawa 1993, s. 14-15.

4 Tytułem przykładu wskazać można na badania W.J. Onga nad relacją pisma i techniki. Zob. W.J. Ong, Osoba, świadomość, komunikacja. Antologia, przeł. J. Japola, Warszawa 2009. 
tworowi graficznemu towarzyszy pewien artefakt, pewna czynność mówienia. Czynność taka jest także nie tylko narzędziem komunikacji, lecz oprócz tego przynależy do warstwy przedmiotów przedstawionych przez autora lub autorów rozważanego źródła. Autor listu sprzed choćby dwustu lat brał często pod uwagę to, jak odbiorca listu wyobrażałby sobie barwę jego głosu, gdyby wiadomość została przekazana osobiście. Warstwa tworów graficznych w przypadku źródła pisanego odsyła jednak także do warstwy pewnych innych jeszcze czynności i rezultatów będących wytworami tych czynności. Patrząc na tekst pisany, można bowiem dostrzegać także krój czcionki, ruch i gesty piszącego, związaną z tym staranność i elegancję. Dlatego można by tu odejść nieco od terminologii Ingardena i zamiast o warstwie językowych tworów brzmieniowych mówić (nawiązując do Twardowskiego) o warstwie artefaktów.

Intencje badania takiej warstwy nie są obce historykom kultury. Jeden z największych historyków kultury, J. Huizinga, w biografii Erazma z Rotterdamu, $\mathrm{w}$ rozdziale dotyczącym charakteru humanisty pisał:

O dwóch rzeczach nie wolno zapominać przy rozpatrywaniu owych mniej sympatycznych cech Erazma. Po pierwsze, że nie wolno go mierzyć miarą naszych pojęć subtelności i taktu. W porównaniu z większością swoich współczesnych, zwłaszcza humanistów Erazm jest umiarkowany, skromny, miły i delikatny. Punkt drugi wyrazić można następująco: nie słyszymy tonu jego słów, nie widzimy już jego uśmiechu ${ }^{5}$.

O ile pierwsza zasada, którą zaleca uwadze badaczy przeszłości holenderski uczony, jest jasna i nie budzi większych wątpliwości, to druga może ich dziwić. Sądzimy jednak, iż nie idzie w tym miejscu o trywialną konstatację tego, że Erazm nie żyje. Nie jest to także spostrzeżenie dotyczące ograniczoności zasobów źródłowych, z którego wynikać powinna daleko idąca wstrzemięźliwość i skromność biografów, choć i to jest ważne. Otóż Huizinga, jako badacz kultury, do tego Erazmiańskiego tonu, którego bezpośrednio nie słyszymy, stara się, i to z powodzeniem, dotrzeć. Odkładając w tym miejscu studia nad metodologią, którą posługiwał się autor Jesieni średniowiecza, zauważmy, że w owym dotarciu do tonu Erazma pomaga właśnie analiza warstwy brzmieniowej. Temu celowi służy szczegółowa i pedantyczna lektura źródeł, której świadectwem jest biografia humanisty z Rotterdamu. Pytanie: jak brzmi dany tekst, jest pytaniem kulturoznawczo doniosłym. Melodia języka jest ważnym elementem świata przeżywanego. Może być świadectwem swoistej witalności, estetyki wypowiedzi, przeżywania czasu, wagi konwersacji oraz relacji między oralnością a piśmiennością ${ }^{6}$. Zwracał na to uwagę choćby zapomniany dziś nieco włoski fenomenolog Enzo Pacci w Dzienniku fenomenologicznym ${ }^{7}$, twierdząc, że historyk kultury nie może pomijać swoistej

5 J. Huizinga, Erazm, przeł. M. Kurecka, Warszawa 1964, s. 174 n.

${ }^{6}$ Por. W.J. Ong, Oralność i piśmienność. Słowo poddane technologii, przeł. J. Japola, Warszawa 2011.

7 E. Pacci, Dziennik fenomenologiczny, [w:] idem, Związki i znaczenia. Eseje wybrane, przeł. S. Kasprzysiak, Warszawa 1980. 
melodii języka, jest ona bowiem integralną częścią świata przeżywanego i stanowi jego wyróżniający element.

4. Kolejną warstwą, którą należy wziąć pod uwagę, jest warstwa jednostek i całości znaczeniowych. Jej analiza wymaga pewnych założeń o charakterze semiotycznym, jest jednak kolejnym naturalnym krokiem w ramach zarysowanego programu badań. Obie wcześniej wspomniane warstwy, tzn. tworów graficznych oraz językowych tworów brzmieniowych, to warstwy obejmujące (używając terminologii Ch.S. Peirce'a) reprezentameny, czyli obiekty reprezentujące, a zatem takie, które zastępują coś ze względu na coś. Reprezentowanie to w takim razie zjawisko, w obrębie którego coś zastępuje coś innego ze względu na coś. To ostatnie „coś” to właśnie podstawa reprezentowania, czyli znaczenie. Warstwa reprezentamenów odsyła więc zawsze do warstwy znaczeń, do owego fundamenta representationis.

Posłużmy się w tym miejscu przykładem. Ilustracją będą przygodnie wybrane do niniejszego studium pamiętniki Ignacego Daszyńskiego ${ }^{8}$.

Już w pierwszych klasach gimnazjum stałem się pod wpływem mego brata gorącym patrjotą (sic!) polskim. Umiałem z nim razem śpiewać wszystkie chyba piosenki powstańcze z r. 1831 i 1863, czytałem książki z dziejów Polski i wyrabiałem sobie nietyle sądy, ile sympatje (sic!) i antypatje dla poszczególnych osób z tych dziejów.

W rozpoznawaniu otaczającego świata orientacja historyczna jest po prostu potrzebna. $\mathrm{W}$ tym wypadku mówimy o wiedzy na temat powstań narodowowyzwoleńczych w XIX wieku, a także okoliczności kształcenia historycznego, które odbywało się na przekór szkole, ponieważ nie była ona szkołą polską. W interpretacji tekstu wiedza o sytuacji Galicji w latach siedemdziesiątych XIX wieku, o utraconej niepodległości, o powstaniach, jest przydatna. Należy jednak pamiętać, że znaczenie historyczne źródła nie tworzy warstwy najważniejszej w procesie poznawania otaczającego świata. Może stać się jego elementem, ale nie musi. Oczywiście bez wiedzy historycznej, bez znajomości tytułów, dat, nazwisk, innymi słowy - tak zwanego kontekstu historycznego - nasze rozpoznania byłyby znacznie uboższe, ale nie niemożliwe.

Należy poświęcić kilka słów problemom interdyscyplinarnym. Zachowując krytyczny stosunek albo przynajmniej dystans do interdyscyplinarności, która w dzisiejszej humanistyce nazbyt często skutkuje utratą przedmiotu badań, trzeba pamiętać o pożytecznych i twórczych powinowactwach między dyscyplinami. Mianowicie, jak w przypadku analizy warstwy graficznej owocne może być korzystanie na przykład z doświadczeń historii sztuki czy archeologii lub też w przypadku warstwy tworów brzmieniowych przydatna może być pomoc historii idei czy literaturoznawstwa, tak w warstwie znaczeniowej często nieodzowna może okazać się pomoc historyków lub historyków literatury. Historyk

8 Analizą akurat tego źródła autorzy zajmują się w innym projekcie badawczym, dotyczącym kultury dwudziestolecia międzywojennego. W tym miejscu źródło pełni tylko i wyłącznie funkcję ilustracyjną, jako tekst pisany i jako dokument osobisty. 
kultury mógłby bowiem popaść w spore problemy interpretacyjne, nadając znaczenie współczesne niegdysiejszym pojęciom. Wyróżnienie takiej warstwy ma więc na celu właściwe rozpoznanie znaczeń pojęć używanych w analizowanych źródłach.

5. Przedmioty przedstawione $\mathrm{w}$ ramach określonego obrazu świata przeżywanego ujmowane są z kolei za pośrednictwem swoich aspektów lub, jak się niekiedy dawniej mówiło, odcieni. Odcieniami przedmiotów przedstawionych w ramach określonego obrazu świata przeżywanego są przede wszystkim wyglądy tych przedmiotów. Podstawowym pytaniem jest, jak określony przedmiot się jawi. Chodzi więc tutaj nie o to, co jest przedmiotem przedstawienia, lecz o to, jak przejawia się to, co jest przedmiotem przedstawienia. W przypadku prostego aktu spostrzeżenia można powiedzieć, że patrzymy na przykład na jednolicie zabarwioną czerwoną kulę, ale widzimy ją jako niejednolicie zabarwioną czerwoną tarczę. Z punktu widzenia badacza kultury istotne jest nie tylko to, co takiego przynależy do obrazu świata przeżywanego przez określony podmiot, lecz także to, jak ów podmiot postrzega to coś, na przykład jakie cechy mu przypisuje. Posłużmy się ponownie przykładem z przywołanych już wspomnień Ignacego Daszyńskiego.

\begin{abstract}
Zbieraliśmy się za miastem w domu pp. D., albo na wycieczkach, nad rzeką Bystrzycą. Ukryci w łozach nadbrzeżnych, tworzyliśmy koło, w którem czytało się książki, często zakazane. Fechtowaliśmy się zajadle pałaszami, karabinami, lancami, gimnastykowaliśmy się z zapałem, pływali, maszerowali, mając ciągle na myśli, że kiedyś to wszystko w powstaniu się przyda [...] Atmosfera, w której wzrastaliśmy była rycerska, przyczem nie zaniedbywaliśmy literatury polskiej i czytaliśmy wielkich poetów polskich z głębokiem nabożeństwem ${ }^{9}$.
\end{abstract}

Nadbrzeżne łozy, brzeg rzeki, książki, szable, łagodne wzgórza - to sceneria buntowniczej młodości Daszyńskiego. Całe to rekwizytorium związane jest zrazu z pewnym charakterystycznym dla tego źródła, i szerzej, dla tej kultury, systemem wyglądów. Widzimy ów świat otaczający, w którym żyje Daszyński. I oczywiście doskonale zdajemy sobie sprawę, że nie mówimy ani o uniwersalnym obrazie dzieciństwa, ani li tylko o konwencji literackiej. Źródło przedstawia nam pewne - takie a nie inne - rekwizyty, kreśli takie a nie inne sceny. Grupa jedenastodwunastoletnich chłopców ucząca się fechtunku, recytująca wiersze patriotyczne na brzegu rzeki Bystrzycy stanowi ów sielsko-patriotyczny obrazek charakterystyczny dla tamtej kultury. Zarazem jednak występuje tuż obok takiego opisu:

W domu był nadzwyczaj surowy system wychowywania dzieci. Kiedy ojciec wchodził do pokoju, wszyscyśmy wstawali i czekali aż siąść pozwoli. Ojciec był do czwartego lub piątego roku dziecka tkliwym i pieszczotliwym; skoro tylko chłopak zaczynał cokolwiek rozumieć, zaczynał się rygor prawdziwie żelazny. Absolutne milczenie w towarzystwie ojca było koniecznym obyczajem, o obcowaniu dzieci z ojcem nie było mowy. Ojciec sam był człowiekiem milczącym i był znany w całej okolicy z wielkiej prawości charakteru. Był on biczem bożym dla każdego blagiera w towarzystwie [...] Ostatnich dziesięć lat życia był ojciec chorym człowiekiem. Uratował się wprawdzie po ataku apoplektycznym, ale musiał bardzo uważać na siebie. Żałowałem całe życie,

9 I. Daszyński, Pamiętniki, Kraków 1925, s. 2. 
że stary niemądry sposób wychowywania dzieci nie dozwolił mi nigdy zbliżyć się serdecznie do ojca. Nauczyłem się dopiero później cenić jego czysty i piękny charakter ${ }^{10}$.

Droga do świata przeżywanego, nawet jeśli jego istotą są wartości, wiedzie zatem i przez tę warstwę, czyli przez wyglądy. Sielski obraz wyłaniający się z pierwszego cytatu współwystępuje z powyższym opisem surowej i smutnej, ale i pełnej czułości relacji z ojcem. Dom, pokój, cisza, choroba i zarazem przestrzeń uczuć łączących ojca z dziećmi zwraca uwagę w opisie. Są to obiekty różnorodne, niemniej jednak wszystkie mieszczą się w omawianej warstwie. Tworzą swoisty dla świata przeżywanego układ dóbr, czyli rzeczy, sytuacji, osób nacechowanych wartościami, który pozwala na przystąpienie do właściwej analizy sposobu bycia podług wartości.

6. Nie mniej ważną warstwą aspektów czy odcieni postrzeganych przedmiotów jest kolejna warstwa - wartości. Otóż każdy przedmiot postrzegany jest także za pośrednictwem wartości, które mu przysługują. Wiąże się to przede wszystkim z tym, jakie oddziaływanie motywacyjne ma postrzegany przedmiot na podmiot, który ten przedmiot postrzega. Kluczowe jest pytanie, do jakich działan motywuje postrzegany przedmiot podmiot, który ten przedmiot postrzega. Badając obraz przeżywanego świata, powinniśmy nie tylko uchwycić, jakie przedmioty przynależą do owego świata, lecz także w jaki sposób przedmioty te motywują podmioty zamieszkujące ów świat do takich lub innych działań. Rekonstrukcja wyglądów, poprzedzająca rekonstrukcję hierarchii wartości, ma też ten sens, że chroni przed jałowym i paraliżującym problemem różnicy między tzw. wartościami deklarowanymi a wyznawanymi. Kiedy sprowadzi się wartości do jakichś quasi-duchowych bytów, istniejących w sferze psychicznej i tylko w niej, wtedy pojawia się namysł nad tymi dwoma „typami” wartości. Wówczas analiza tekstu staje się właściwie niemożliwa i z podejrzliwością traktuje się każdą autorską deklarację i wyznanie. Tekst analizuje się przeciw autorowi. Kiedy jednak osadzi się warstwę wartości w warstwie wyglądów, przedstawień i przedmiotów suponowanych, problem znika, wartości wyrażone są bowiem także przez system wyglądów. O wadze patriotyzmu w świecie Daszyńskiego przekonujemy się nie wtedy, gdy autor zadeklaruje, że jest patriotą, ale wówczas gdy z ewidentną czułością, miłością i dumą opowiada, jak kilkuletni chłopcy, bawiąc się $\mathrm{w}$ wojnę, przygotowywali się do powstania, jak wbrew szkole, która czyniła z Polaków „marnych serwilistów”, uczyli się historii Polski i romantycznych wierszy. W rekonstrukcji świata wartości posługujemy się typologią wartości. Na podstawie wieloletniej praktyki badawczej możemy stwierdzić, że szczególnie cenna jest typologia zaproponowana przez Maxa Schelera ${ }^{11}$. Oczywiście pomijamy zagadnienia ontologiczne związane z koncepcją wartości tego wybitnego aksjologa, a koncentrujemy się tylko i wyłącznie na kwestiach metodologicznych. Pierwszorzędnym zadaniem historyka kultury jest po pierwsze uchwycenie danych typów wartości

10 Ibidem, s. 7.

11 M. Scheler, Der Formalismus in der Ethik und di materiale Wertethik, Francke-Verlag-Bern 1954, s. 125-131. 
w analizowanym źródle, a po wtóre ułożenie ich we właściwej dla tego źródła hierarchii. W przytoczonych $\mathrm{w}$ rozdziale pięciu cytatach najważniejsze są dwa typy wartości, witalne oraz prawne. Dla bawiących się chłopców patriotyzm jest czymś oczywistym i poważnym. Dają wyraz niezwykłemu przywiązaniu do polskości, do polskiej historii i literatury. Nawet rytm codziennych zabaw określony jest przez plany narodowej irredenty. Wyraźne jest także przywiązanie do wspólnoty, do koleżeństwa, do przyjaźni. „Tworzyliśmy koło” - jak pisał Daszyński o grupie, która do zabaw dołączała wspólne ćwiczenie fizyczne i kształcenie się. Drugi cytat jest zaś świadectwem wysokiej rangi, jaką lider ruchu socjalistycznego nadawał rodzinie - poruszający obraz miłości do ojca, która z powodów kulturowych nie mogła być należycie odwzajemniona. Wyraźnie i ostro krytykuje „stary i niemądry sposób wychowywania dzieci”, uniemożliwiający nawiązanie głębszych relacji. Wartości prawne współwystępują więc $\mathrm{z}$ antywartościami. $\mathrm{Z}$ jednej strony jest to niesprawiedliwość polityczna i narodowa, nastolatkowie bowiem są buntownikami, działają wbrew obowiązującemu prawu. Czynią to jednak w imię sprawiedliwości. W drugim wypadku konstrukcja jest podobna. Daszyński upomina się o więzi rodzinne przeciw obowiązującym obyczajom. Obserwujemy więc zasadniczy spór toczony w obszarze tego samego typu wartości. Obok prawnych dostrzegamy wartości witalne. Chłopcy, z dzisiejszej perspektywy dzieci, ćwiczą, fechtują, pływają i maszerują. Co więcej, Daszyński pisze o zajadłości i zapale do ćwiczeń. Możemy w ścisłym tego słowa znaczeniu mówić o ascezie w życiu tych chłopców. W opisie relacji z ojcem wartości witalne nie dominują już tak znacząco, ale nie sposób przeoczyć trzech aspektów: rangi dyscypliny w procesie wychowawczym, uwagi, z jaką autor informuje o chorobie ojca oraz siły (!) uczuć. Tę uczuciowość interpretujemy także witalnie. Wartościami, które dają się dostrzec, są wartości religijne. Jakkolwiek przywołane metaforycznie, to sam fakt takich porównań nie może być pominięty w analizie kulturoznawczej. Informując o wspólnych lekturach, Daszyński pisze o głębokim nabożeństwie, $\mathrm{z}$ jakim odnoszono się do książek. Z kolei o ojcu pisze jako o biczu bożym na wszelkich blagierów. W tym ostatnim wątku znowu pojawiają się wartości prawne, a także poznawcze. Ojciec Ignacego jest przedstawiony jako wróg kłamstwa i pozerstwa. $Z$ kolei spotkania koła przeznaczone były nie tylko na ćwiczenia fechtunku i pływania, lecz także na systematyczne poznawanie historii i literatury polskiej. W cytowanych fragmentach na szczycie hierarchii wartości pojawiają się wartości prawne (naród, wspólnota przyjaciół, rodzina) oraz witalne (odwaga, siła, dyscyplina). Tuż poniżej usytuować należy wartości poznawcze (poznanie, prawda, prawdomówność) oraz religijne. Zaledwie wspomniane są wartości estetyczne, przy czym za piękny uznaje się tu charakter i postawę życiową. Wartości utylitarne nie pojawiają się, a hedonistyczne możemy jedynie domniemywać z sensualnych opisów, ale na pewno nie zajmują one eksponowanego miejsca w świecie wartości Daszyńskiego.

7. Dochodzimy wreszcie do warstwy samych przedmiotów przedstawionych. Otóż z metodologicznego punktu widzenia istotnym pytaniem jest nie 
tylko pytanie o to, jakie przedmioty przedstawione tworzą substancję obrazu przeżywanego światu, lecz także o to, jakie zależności występują między tymi przedmiotami. Każdy przedmiot przedstawiony jest bowiem przedstawiony jako przedmiot uwikłany $\mathrm{w}$ relacje $\mathrm{z}$ innymi przedmiotami. Wiele jego cech to zatem takie cechy, które przysługują mu ze względu na relacje, w jakich pozostaje $z$ innymi przedmiotami. Ponadto, każdy przedmiot przedstawiony powinien zostać ujęty jako przedmiot stanowiący element pewnej struktury relacyjnej, czyli pewnego kompleksu przedmiotów połączonych z sobą różnorodnymi relacjami. Pierwszym z pytań dotyczących przedmiotów występujących w obrębie pewnego określonego systemu relacyjnego jest pytanie o to, czy w systemie tym występują elementy centralne. Czym zatem jest element centralny? W dowolnie ustalonym systemie relacyjnym $\mathrm{X}$ obiekt $\mathrm{Y}$ nazwiemy elementem centralnym w systemie $\mathrm{X}$ wtedy i tylko wtedy, gdy to, czy między elementami A i B systemu X zachodzi dowolna relacja R zależy od tego, czy między elementami A i Y zachodzi pewna relacja $\mathrm{R}_{1}$ oraz między elementami $\mathrm{B}$ i Y zachodzi pewna relacja $\mathrm{R}_{2}$. A zatem każda relacja zachodząca między obiektami (elementami) A i B jest zależna od tego, czy obiekt A pozostaje w pewnej relacji do Y i czy obiekt B pozostaje w pewnej relacji do Y. Element centralny w określonym systemie relacyjnym to zatem taki przedmiot, który ze względu na relacje, $w$ jakich pozostaje do innych przedmiotów, wyznacza wszystkie inne relacje zachodzące między dowolnymi przedmiotami w obrębie tego systemu relacyjnego. Oczywiście szczegółowe założenia metodologiczne mogą przesądzać, że badane uniwersum ujmowane jest jako system relacyjny $z$ jednym elementem centralnym albo jako system relacyjny o wielu (lecz skończenie wielu) elementach centralnych. Z czysto teoretycznego punktu widzenia można oczywiście przyjąć, że badane uniwersum nie zawiera w ogóle elementów centralnych lub że zawiera ich nieskończenie wiele. Założenia takie nie są jednak, naszym zdaniem, płodne teoretycznie, natomiast określenie takich zależności jest zadaniem istotnym. Zrobiliśmy to w interpretacji wartości prawnych, kiedy konieczne było rozstrzygnięcie relacji między rozmaitymi wartościami tego typu. Obyczaj skonfliktowany był z czułością rodzicielską, a porządek prawny z poczuciem sprawiedliwości. Daszyński z pewnością nie był lojalistą, a przecież w hierarchii wartości związanej z postawą lojalistyczną wartości prawne zajmują niekiedy najwyższe miejsce. Określenie szczegółowych relacji w systemie wartości jest więc zadaniem nieodzownym. Ontologiczne zależności przekładamy na struktury świata przedstawionego, na zależności bytowe, przy czym przełożenie rozważań ontologicznych na żmudną praxis historyka kultury sprawić może wrażenie trywializacji. Ale nie może być inaczej, skoro podejmujemy się rekonstrukcji świata życia codziennego. O postawie i hierarchii wartości świadczy przecież także wyznawana koncepcja człowieka, świata czy Boga. W świecie przeżywanym możemy odkryć powiązania między preferencjami politycznymi a gustem muzycznym albo sposobem ubierania. W tym miejscu dotykamy już bardziej złożonej kwestii. 
8. Spośród wielu relacji, które zachodzić mogą między przedmiotami badanego uniwersum, na szczególną uwagę zasługuje ontologiczna relacja, zachodząca między przedmiotami abstrakcyjnymi a stanowiącymi ich podłoże przedmiotami k o n k r e t n y $\mathrm{m}$ i. Tłem i punktem odniesienia w rozważaniach będą obszerne analizy Husserla zawarte w tomie drugim Badań logicznych ${ }^{12}$. Przedmiot abstrakcyjny to taki przedmiot, którego forma sprawia, że aby istnieć, musi on współistnieć $\mathrm{z}$ pewnym innym przedmiotem (lub $\mathrm{z}$ pewnymi innymi przedmiotami) w obrębie większej całości. Przykładem przedmiotu abstrakcyjnego jest choćby cecha pewnej rzeczy, np. zabarwienie (pewnego określonego) jabłka. Cecha pewnej rzeczy może bowiem istnieć tylko wraz z tą rzeczą. Jest a tr y bu te $m$ tejże rzeczy, rzecz ta stanowi zaś dla niej sub st a n cj ę, czyli konieczne dla niej podłoże. Można także powiedzieć, że cecha taka jest u f u n d o wa n a w rzeczy, której przysługuje. Husserl często łączy pojęcie przedmiotu abstrakcyjnego z pojęciem części abstrakcyjnej pewnego przedmiotu. Chodzi o to, że wyróżniając w pewnym przedmiocie jego części, można dokonać rozróżnienia na części samodzielne tego przedmiotu (inaczej kawałki), które mogą istnieć samodzielnie po oddzieleniu ich od tego przedmiotu, oraz na części niesamodzielne tego przedmiotu (inaczej momenty), które nie mogą istnieć w oddzieleniu od tego przedmiotu. Na przykład za część (pewnego określonego) jabłka można uznać zarówno zabarwienie tego jabłka, jak i jego ogonek lub każdą jego pestkę. Oczywiście ogonek lub pestka tego jabłka to przedmioty konkretne, mogą one bowiem istnieć niezależnie od tego, czy jabłko to istnieje czy też nie. Nie są więc one ufundowane w tym jabłku, są jego częściami, lecz nie atrybutami. Nie każdy przedmiot abstrakcyjny jest jednak częścią przedmiotu, w którym jest ufundowany. Załóżmy, że na stole, przy którym właśnie siedzimy, leży (pewne określone) jabłko i (pewna określona) gruszka. Weźmy teraz pod uwagę odległość, jaka dzieli to jabłko od tej gruszki. Oczywiście odległość ta może istnieć jedynie, współistniejąc z tym jabłkiem i z tą gruszką w obrębie pewnej większej całości. Jest ona zatem ufundowana zarówno w tym jabłku, jak i w tej gruszce - jest więc czymś abstrakcyjnym. Nie jest ona jednak ani częścią tego jabłka, ani częścią tej gruszki. Tą większą całością, w obrębie której odległość ta, aby istnieć, musi współistnieć z tym jabłkiem i z tą gruszką, nie jest bowiem ani to jabłko, ani ta gruszka, lecz stan rzeczy polegający na tym, że to jabłko leży w pewnej odległości od tej gruszki ${ }^{13}$. Przedmiot ko nkretny to natomiast taki, który aby istnieć nie musi wcale współistnieć z pewnym innym przedmiotem (lub z pewnymi innymi przedmiotami) w obrębie pewnej większej całości. Przykładem przedmiotu konkretnego będzie więc zarówno pewne jabłko,

12 Badanie II, Idealna jedność species a nowożytne teorie abstrakcji oraz Badanie III, Z nauki o całościach i częściach, [w:] E. Husserl, Badania logiczne, t. II. Badania dotyczące fenomenologii i teorii poznania, cz. I, Warszawa 2000, s. 131-274, 275-366.

13 Oczywiście jest tak pod warunkiem, że odrzuca się tzw. teorię relacji wewnętrznych. Teoria ta była rozwijana np. w neoidealizmie brytyjskim. W sprawie teorii relacji wewnętrznych zob. J. Swift, Podróże Guliwera, przeł. L. Żelaziewicz, Wrocław 1988, s. 187. 
pewna gruszka, jak i ogonek czy pestka tego jabłka lub tej gruszki. Oczywiście przedmiot abstrakcyjny może być także ufundowany w wielu różnych przedmiotach, które stanowią dla niego konieczne podłoże. Istotne jest tutaj pytanie, które z przedmiotów przynależących do badanego uniwersum, czyli przedmiotów należących do świata przeżywanego i w znacznej mierze wyznaczających obraz tego świata to przedmioty konkretne, a które to przedmioty abstrakcyjne. Jak już powiedzieliśmy, każdy przedmiot abstrakcyjny jest ufundowany w pewnym innym przedmiocie, który stanowi jego substancję lub, inaczej mówiąc, jest jego podłożem. Ten ostatni przedmiot może z kolei być zarówno przedmiotem konkretnym, jak i abstrakcyjnym. W tym ostatnim wypadku wymaga on znowu kolejnego przedmiotu, w którym jest ufundowany. Jeśli teraz spojrzymy na uniwersum ontologiczne (czyli na klasę wszystkich możliwych przedmiotów) pod kątem porząakującego to uniwersum stosunku ufundowania, to możemy zapytać, czy możliwe są nieskończone zstępujące łańcuchy przedmiotów uporządkowanych przez tenże stosunek. Jeśli nie, to każdy przedmiot jest ostatecznie ufundowany w przedmiocie lub w przedmiotach, które same nie wymagają już ufundowania, czyli są konkretne. Przedmioty takie to substancje pierwsze ${ }^{14}$. Pogląd, że każdy przedmiot jest ostatecznie ufundowany w substancjach pierwszych, ma długą historię. Teorie ontologiczne, które przyjmują ten pogląd, nazywać będziemy ontologiami ufundowanymi. Pojawia się więc kolejne pytanie - czy ontologia świata przeżywanego, do którego odsyła nas źródło, to ontologia ufundowana. Można bowiem zapytać, czy ontologie ufundowane są tak oczywiste, że nie powinny być podważane. Zobaczmy zatem, jakie konsekwencje przynieść może odrzucenie założenia o ufundowaniu. Po pierwsze, może to prowadzić do poglądu, że możliwe są nieskończone zstępujące łańcuchy przedmiotów uporządkowanych przez stosunek ufundowania. W tym wypadku mamy do czynienia z pewną postacią regresu ad infinitum. Sytuacja taka nie jest oczywiście logicznie niemożliwa, lecz na pewno w tradycji filozoficznej nie była nigdy mile widziana. Po drugie, może to prowadzić do poglądu, że możliwe są pary, trójki czy ogólniej entki przedmiotów, które wzajemnie się fundują. Po trzecie, możliwa jest także sytuacja, w której co prawda każdy przedmiot jest ostatecznie ufundowany w pewnych przedmiotach podstawowych (nazwijmy je przedmiotami pierwszego rzędu), ale przedmioty te nie są substancjami pierwszymi, lecz pewnymi kompleksami wzajemnie się fundujących przedmiotów. Obiekt pierwszego rzędu może więc tu być całością zbudowaną z części, które są względem siebie wzajemnie niesamodzielne, lecz razem tworzą pewną samodzielną całość.

W praktyce badawczej warstwa wartości, przedmiotów oraz relacji między przedmiotami współwystępuje $\mathrm{w}$ tym samym czasie. Analiza poszczególnych części źródła nie pozwala na ich wyraźne oddzielenie. Wartości przedmiotu wychwytujemy wraz z relacjami między elementami świata przedstawionego i wraz

14 Używamy tu terminu, i jedynie terminu, wprowadzonego przez Arystotelesa. 
z hierarchią wartości danego obiektu. Są to jednak różne warstwy, a ich jasne i wyraźne pojęcie ułatwia analizę. Dlatego przykłady, które podajemy w poszczególnych częściach, odnoszą się do kilku warstw. Wspominaliśmy już o patriotyzmie Daszyńskiego. Oto kolejny cytat:

Z góry też patrzyliśmy na tromtadrację i kłamliwy patriotyzm kołtunów noszących podczas różnych występów konfederatki i kontusze.

Burmistrzem Stanisławowa był głośny swego czasu poseł Kamiński, który dopuścił się nieczystych sprawek przy budowie kolei transwersalnej i musiał złożyć mandat. Chodził oczywiście w kontuszu przy każdej uroczystości. Do szału doprowadzały nas jego słowa, jak: „najjaśniejszy Pan pozwala nam mówić po polsku”, za co winni mu Polacy wdzięcznośćc 15 .

A w innym miejscu:

W naszych oczach pojęcie Polaka było równoznacznem z człowiekiem szlachetnym, chętnym do największych ofiar dla ojczyzny i pracującym dla jej jak najrychlejszego oswobodzenia. Dlatego z nieufnością patrzyliśmy na tych co swoją polskość głównie kontuszem okazywali. Mieliśmy przed sobą przykłady najmarniejszej hołoty ludzkiej, odziewającej się w czamary i szukającej tym sposobem szacunku ludzkiego nic dziwnego, że nie sprzyjaliśmy czapkom na zawiasach ${ }^{16}$.

Stosunek do stroju, jego elementów czy szerzej - do mody ma bezdyskusyjne związki z wartościami duchowymi, takimi jak patriotyzm. Konfederatki i kontusze budzą u Daszyńskiego li tylko pogardę i nienawiść. Co więcej, opowiada o tym, że współwystępowały z lojalizmem najgorszego sortu, a zatem to, że w ogóle są noszone, ma znaczenie i nie można tego bagatelizować, ale należy uwzględnić szerszy kontekst. Podkreślmy, że nie idzie o poszerzenie podstaw źródłowych. Pozostając w świecie tekstu Pamiętnika, należy odkryć powiązania, nazwać je i przypisać im określone wartości. W powyższym cytacie jest też mowa o szlachectwie w dwóch rożnych znaczeniach, kluczowych zresztą dla Daszyńskiego. Szlacheckość to po prostu szlachetność, której najistotniejszą częścią jest miłość do ojczyzny, jednakże szlacheckość to też styl ubierania się najgorszej hołoty. Zauważmy, że świat społeczny polskiego socjalisty jest hierarchiczny. Nadal są w nim ci szlachetni, waleczni, rycerscy i honorowi oraz czerń i hołota. Tyle że patriotyczną szlachtą są socjaliści, a ciemnymi, brutalnym lojalistami — galicyjscy posiadacze ziemscy, którzy, nie wiedzieć czemu, uważają się za szlachtę. Ich szlachectwo jest moralnym nadużyciem i społecznym uroszczeniem. Jeszcze dobitniej, choć w innym świetle, widać to tym oto fragmencie:

W mojej późniejszej walce politycznej z panującem, w kraju stronnictwem, używano przeciw mnie często śmiesznego argumentu, że zwalczam szlachetczyznę, a sam jestem szlachcicem... Otóż co do tego szlachectwa mojego, rzecz jest dla mnie zupełnie niejasna. Matka była wprawdzie herbową szlachcianką (herbu Leliwa), ale ojcowskie szlachectwo było mocno niezdecydowane. Późniejszy mój kolega w krakowskiej radzie miejskiej, dr Ponikło, wyszperał w warszawskich aktach, że jakiś Tomasz Daszyński stał przed sądem królewskim w obozie pod Połockiem,

\footnotetext{
15 I. Daszyński, op. cit., s. 8.

16 Ibidem.
} 
w r. 1517 za zabicie brata szlachcica i został grzywną ukarany, ale czy miał ona jakikolwiek związek z moją rodziną, tego nie wiem. Ani w domu nikt nam szlachectwa w głowę nie wkładał, ani ja później nigdy za żadnego szlachcica nie uważałem się i dlatego nie traktowałem argumentu przeciwników politycznych inaczej jak humorystycznie ${ }^{17}$.

Ignacy Daszyński, szlachcic po matce i najpewniej po ojcu, szlachectwa swego się wypiera, zarzutów szlachetczyzny się wstydzi. I — jak można żartobliwie to skomentować - tak się wypiera, że aż potwierdza. Ów wąsaty, postawny, sprawny i silny fizycznie socjalista mógłby uchodzić za stereotypowego Sarmatę. Więcej nawet - on jest kulturowym Sarmatą. Musimy jednak uchwycić powiązania między różnymi elementami jego świata przeżywanego. Nie wystarczy skonstatować hierarchię wartości, podług której żył, lecz także powiązania między różnymi elementami jego świata. Przeczytamy bowiem w pamiętniku fragmenty bardzo krytyczne wobec szlachty dziewiętnastowiecznej, a zarazem uważna analiza pokaże, że hierarchię wartości późniejszego lidera PPS-u można scharakteryzować właśnie jako szlachecką. Kluczowe nie jest bowiem użycie takiego czy innego pojęcia, ale bogata i wielowarstwowa struktura łącząca rozmaite elementy świata przeżywanego. Jednakże nawet taka struktura nie wyczerpuje możliwości analizy kulturoznawczej dokumentu osobistego.

9. Jak już wspomniano, każdy przedmiot przedstawiony stanowiący zawartość obrazu świata przeżywanego jest zarazem przedmiotem uwikłanym w jakąś sytuację. Źródło pokazuje bowiem pewne przedmioty, zarazem coś twierdząc, czemuś przecząc lub coś suponując jako możliwe, niemożliwe, przypuszczalne, spodziewane itp. Warstwa przedmiotów przedstawionych odsyła więc do warstwy sytuacji suponowanych, gdyż każdy przedmiot zyskuje swe określenia jedynie w ramach sytuacji, w które jest uwikłany. Jest zawsze jakiś, a to, jaki jest, zależy od sytuacji, które go dotyczą. Należy podkreślić, że nie chodzi tylko o takie sytuacje, które zostały w ramach źródła stwierdzone. Jeśli na przykład twierdzi się, że ktoś nigdy nie złamie danego słowa, to sytuacja polegająca na złamaniu danego słowa w sposób istotny charakteryzuje tego kogoś, chociaż twierdzi się, że sytuacja ta nigdy nie występuje. Warstwa sytuacji suponowanych obejmuje więc wszystko to, co się twierdzi, wszystko to, czemu się przeczy i, mówiąc ogólnie, wszystko to, co możliwe. Istotnym pytaniem metodologicznym jest zatem także pytanie o to, jakie sytuacje to sytuacje możliwe z punktu widzenia źródła, czyli o to, jaka jest przestrzeń światów możliwych, do których źródło odsyła.

U Bernardynów byłem zawsze bardzo dobrym uczniem. Jeden, ks. Rzepka był uosobioną dobrocią i słodyczą. Szeroki w plecach, blondyn, młody jeszcze, miał tak serdeczny i słodki uśmiech na ogolonej pełnej twarzy, że dotąd jeszcze odczuwam silną przyjemność, gdy o nim wspomnę ${ }^{18}$.

\footnotetext{
17 Ibidem, s. 6 .

18 Ibidem, s. 3.
} 
Łatwo ulec w tym miejscu pokusie prezentystycznej lektury, uruchamiającej skojarzenia kulturowe charakterystyczne dla naszego świata przeżywanego, nie zaś dla świata, w którym żył Ignacy Daszyński. Dlatego między innymi tak ważne jest pytanie o światy możliwe. W analizie historyczno-kulturalnej poszukujemy zatem tego, co możliwe, co (subiektywnie) konieczne, co powinne itp. Zwróćmy uwagę, że powyższy opis jest dzisiaj niemożliwy, że Ignacy Daszyński nie mógłby w ten sposób wspominać księdza, ponieważ zupełnie jasne byłyby skojarzenia i treści homoseksualne. Wielosłowne podkreślanie męskiej urody, pointowane wyznaniem przyjemności związanej już choćby ze wspomnieniem księdza Rzepki, w naszym świecie wiązałoby się z konieczności z daleko posuniętą seksualizacją takich wyznań. Tymczasem źródło nie daje nam najmniejszych podstaw do takich rekonstrukcji. Mamy badawczy obowiązek pytać o to, co możliwe w danym świecie, ale według prawideł danych przez ten świat czy też mieszczących się w jego granicach. Warto też wspomnieć o jednym $\mathrm{z}$ demonów analizy kulturoznawczej - o frazie „wiadomo, że”. Właśnie w takich sytuacjach, jak powyższy cytat, my doskonale wiemy, jak było naprawdę. Tymczasem historyk kultury na wstępie wiedzieć nie może, gdyż nawet to, co możliwe, ufundowane ma być na tym, co obecne jest w źródle.

10. Wychodząc od pytania, czym może być i czym powinno być źródło dla historyka kultury, przyjmując przy tym, że przedmiotem historii kultury jest świat przeżywany oraz inspirując się analizami warstw dzieła literackiego, przeprowadzonymi przez R. Ingardena, przedstawiliśmy siedem warstw źródła pisanego. Nie wszystkie w równym stopniu wykorzystujemy w badaniach szczegółowych, lecz wszystkie pozwalają na uchwycenie ważnych elementów świata przeżywanego. Namysł nad całościowym ujęciem źródła w badaniach historyczno-kulturowych, charakterystyka poszczególnych warstw oraz powiązań między nimi pozwala nie tyko wzbogacić warsztat analizy kulturoznawczej, lecz otwiera także horyzont dociekań nad interdyscyplinarnością takich badań i możliwą współpracą między przedstawicielami różnych dyscyplin. Analiza świata przeżywanego wyłaniającego się ze źródła historycznego powinna odbywać się z uwzględnieniem jego reguł i jego możliwych interpretacji, niewynikających $z$ naszych współczesnych przekonań i doświadczeń, z tego, co dla nas dziś „oczywiste”, lecz kontekstu całości rekonstruowanej hierarchii wartości.

\section{Bibliografia}

\section{Daszyński I., Pamiętniki, Kraków 1925.}

Huizinga J., Erazm, przeł. M. Kurecka, Warszawa 1964.

Husserl E., Badania logiczne, t. II. Badania dotyczace fenomenologii i teorii poznania. Czesść I, przeł.

J Sidorek, tłum. przejrzał A. Półtawski, Warszawa 2000.

Husserl E., Kryzys europejskiego człowieczeństwa a filozofia, przeł. J. Sidorek, Warszawa 1993.

Ingarden R., O dziele literackim, przeł. M. Turowicz, Warszawa 1960. 
Ong W.J., Oralność i piśmienność. Słowo poddane technologii, przeł. J. Japola, Warszawa 2011.

Ong W.J., Osoba, świadomość, komunikacja. Antologia, przeł. J. Japola, Warszawa 2009.

Pacci E., Dziennik fenomenologiczny, [w:] idem, Związki i znaczenia. Eseje wybrane, przeł. S. Kasprzysiak, Warszawa 1980.

Scheler M., Der Formalismus in der Ethik und di materiale Wertethik, Francke-Verlag-Bern 1954.

Swift J., Podróże Guliwera, przeł L. Żelaziewicz, Wrocław 1988.

\section{Ontological aspects of interpretation of personal documents}

\section{Summary}

What historical source is and how it should be perceived by a historian, when the object of history of culture is understood as Husserlian Lebenswelt? Inspired by R. Ingarden's analyses of literature we present seven layers of written historical source. Although not all of them are utilized in the actual historical investigation, they enable to grasp important elements of the Lebenswelt. An effort to elaborate a complete theory of historical source in history of culture as well as description of the layers and their interrelations will not only enrich historian's toolset but will also open a field for investigations of interdisciplinary nature of such research and possible collaboration between representatives of other disciplines. Analysis of the Lebenswelt present in the historical source should be concerned with its own constraints and possible interpretations whereas the latter should not be derived from our contemporary views and experiences (which are "obvious" to us) but instead they should be done in the context of hierarchy of values as it is presented in the analyzed text. 